Right now, a woman turned away from her pharmacist has only one option for emergency contraception: getting a copper IUD inserted into her uterus by a physician. Copper IUDs are more than $99 \%$ effective at preventing pregnancy, but they can be expensive (up to several hundred dollars) and finding a doctor to insert the device within the recommended 120 hours can be difficult. One American study shows $85 \%$ of clinicians never recommend the device for emergency contraception, and $93 \%$ required two or more visits for an insertion.
The intimate nature of insertion, and the fact that IUDs can cause heavier, longer and more painful periods, also means the device isn't appropriate for everyone, says Guilbert.

A new emergency contraceptive drug, ulipristal acetate, will become available in Canada under the brand name Ella in the fall this year. The drug is currently available as an emergency contraceptive in Europe and the United States. There's evidence it's also more effective than levonorgestrel for women with a BMI over 30, says Guilbert. "The risk of unintended pregnancy is much less, like $2.5 \%$, compared to almost $6 \%$ for women using levonorgestrel."

However, the introduction of Ella won't dramatically improve access to emergency contraception for heavier women, as the drug will only be available by prescription. "It could take one or two years before it can become over the counter," explains Guilbert. In the meantime, "Health Canada should withdraw their recommendations regarding weight and levonorgestrel." — Lauren Vogel, CMAJ

CMAJ 2015. DOI:10.1503/cmaj.109-5098

\title{
Why the fuss over disclosure of physician billings?
}

$\mathrm{D}$ isclose the names, implored the Information and Privacy Commissioner of Newfoundland and Labrador. Do not disclose the names, ruled the Nova Scotia Court of Appeal. Disclose the names, ordered the United States government, ending more than 30 years of legal battles over whether the names should be disclosed.

The locations may change but the struggle remains the same. If you ask for physicians' billing data - with names for government-funded medical services, don't expect to get them without a fight.

But why do most medical associations work so hard to keep this information private? Is it really that big of a deal? After all, there are places, such as British Columbia and Manitoba, where physicians' medicare billings have been public knowledge for decades. Has the medical profession in these areas actually suffered as a result?

"I think most people will fight against other people looking at their salaries until it has been made public," said Kevin McNamara, former deputy minister of health and wellness for Nova Scotia. "But I think that after a year or two, it doesn't matter anymore."

Indeed, many of the oft-repeated arguments about disclosure appear to be more about principles and anomalies than widespread harms or benefits. Those in favour say it's about transparency and accountability in a health system funded with public money, and also about sussing out the few who are defrauding the system. Those against disclosure say it's an invasion of privacy, will be used to embarrass productive doctors and doesn't take into account the cost of staff, equipment and other overhead.

In Canada, one argument often made by medical associations against disclosing individual billings is that it will be used by provincial governments as leverage in contract negotiations with physicians. If negotiations break down, naming and shaming the highest earners becomes an option. That concern is not unfounded, according to Graham Steele, former finance minister for Nova Scotia.

There are legitimate arguments to be made for greater transparency in any negotiation or discussion about physician pay, said Steele. Physician remuneration consumes a huge amount of provincial budgets but receives little public discussion, he said. "If the facts are only known to insiders, you can't have a sensible public debate."

Still, acknowledged Steele, it often comes down to politics. In 2006, Steele, a lawyer by training, was involved in a court case that pushed for the release of individual physician billings. The court decided, that existing freedom-of-information laws did not require this information be made available. In the end, said Steele, it didn't really matter.

"Let's be frank, the public doesn't care, not in the sense of people getting worked up, but the doctors were very worked up."
If the judge had ruled in favour of disclosure, though, would it have given the province the upper hand, a weapon to shame "million-dollar" doctors and win public support for cuts to medical fees? Again, let's consider BC and Manitoba. Has it made a difference in those provinces? Well, if you're looking for evidence, you won't find any, says Jeremiah Hurley, the chair of economics at McMaster University and a member of the Centre for Health Economics and Policy Analysis.

In his opinion, this information doesn't have a big impact on negotiations. "I have no reason to believe that $\mathrm{BC}$ physicians are paid a lot less because it is published."

In $\mathrm{BC}$, the gross medicare billings of all doctors have been publicly available since 1971 in the Blue Book. Although, politicians and reporters tend to be among the most interested in the Blue Book, physicians are also quite curious about its contents. "It does breed some resentment," said Dr. David Attwell, president of the statutory negotiating committee for Doctors of BC.

Public disclosure of physician billings doesn't appear to discourage doctors from seeking work in the province. "but it does have a negative impact on morale," said Attwell. "The high-billers are just going to take cover and ignore it. The low-billers read it and may misinterpret it." - Roger Collier, CMAJ

CMAJ 2015. DOI:10.1503/cmaj.109-5044 